\title{
THE EFFECT OF ETHER UPON THE GERMINATION OF SEEDS AND SPORES. ${ }^{x}$
}

C. O. TOWNSEND.

IN $1896-7$, while carrying on a series of experiments for the purpose of determining the influence of injury upon growth, the writer found that an atmosphere of ether caused considerable variation in the rate of growth of seedlings. The thought presented itself that it would be of interest and of importance to determine the influence of an atmosphere of ether upon the germination of seeds and spores. Accordingly, the following experiments were undertaken and carried on during the winter of $1897-8$ in the laboratory of Barnard College. Seeds for the purpose were soaked in pure water for twenty-four hours in ordinary room temperature, and then transferred to air-tight damp chambers, which contained respectively $1,2.5,5$, and $10^{c e}$ of ether dissolved in ${ } \mathrm{IOO}^{\mathrm{ce}}$ of water. The damp chambers consisted of bell jars, having a capacity of about four liters each, the sides of which were lined with blotting paper saturated with water. In each series of experiments one chamber contained atmospheric air for control. The seeds used were those of Zea Mais, Avena sativa, Phaseolus vulgaris, and Cucurbita Pepo.

\section{EXPERIMENTS WITH SEEDS.}

In comparing the normal rate of germination with the germination of seeds in an atmosphere of $\mathrm{I}^{\mathrm{ce}}$ of ether, it was found that germination was somewhat accelerated by the ether. The germination in the ether atmosphere began twelve to sixteen hours earlier than in the ether-free atmosphere. At the end of the following five days, however, the growth of the seedlings in the ether-free atmosphere exceeded the growth of the seedlings in the atmosphere containing $\mathrm{I}^{\mathrm{ec}}$ of ether, so that the difference in the length of roots of corn varied in the ratio of 35 to 20 in

${ }^{1}$ Read before Section G, A. A. A. S., Boston, 1898 . 
favor of the ether-free atmosphere (table I). With the other seedlings the difference was less marked (tables II, III, and IV). The variation in the growth of shoots or leaves was very slight, being only I 4 to Io and I 2 to 9 in favor of the ether-free atmosphere (tables II and III). ${ }^{2}$ In tables I-IV the germination was perceptibly hastened by the presence of a small amount of ether in the atmosphere. The advantage was soon lost, however, after the seeds in the control experiment germinated. Even if the seeds in the atmosphere of ether were placed in an atmosphere of pure air as soon as they had germinated, they were soon equaled and often exceeded by the seedlings in the control experiment; hence it is impossible to conceive of any commercial advantage in the use of ether to force the germination of seeds under the conditions of these experiments. It might be mentioned in this connection that in the work of the writer on "The correlation of growth under the influence of injury," ${ }^{3}$ the same conclusions were reached in regard to the influence of a weak atmosphere of ether upon the growth of seedlings.

In the experiments in which $2.5^{\text {ee }}$ of ether were used it was found, as in the preceding case, that ether exerts a stronger influence upon some seeds than upon others, although in this case the tendency was to retard germination; e. g., corn germinated in an atmosphere containing $2.5^{\mathrm{cc}}$ of ether in the same time that it did in the control experiment, while the germination of oats was retarded fully 48 hours. It would seem in this case that the ether exerted a double influence upon the germination of the corn; one tendency being to hasten the germination, the other to retard it. The two influences, being equal, neutralized each other, producing no visible effect upon the time of germination. In tables II, III, and IV, the tendency to retard pre-

${ }^{2}$ It should be noted that in a consular report for 1896 reference is made to some experiments with ether upon growing plants, in which there seems to have been a very striking degree of acceleration in favor of a weak atmosphere of ether. It is to be regretted that the report does not give a detailed account of the method employed, since the acceleration seems to have been great enough to be of some practical advantage.

${ }^{3}$ Annals of Botany Ir': 509-532. 1897 . 
dominates, hence the time required for the germination of these seeds was prolonged. After germination began, the growth of roots and leaves was retarded by the ether in all of the seedlings.

TABLES I-IV. SEEDS.

Seeds soaked 24 hours in pure water, then placed in damp chamber. Temp. $18^{\circ} \mathrm{C}$.

\section{Zea Mais.}

\begin{tabular}{|c|c|c|c|c|c|}
\hline $\begin{array}{l}\mathrm{Cc} \text { of ether in } \\
\text { chamber }\end{array}$ & $\begin{array}{l}\text { Number of hours } \\
\text { required for ger- } \\
\text { mination }\end{array}$ & $\begin{array}{l}\text { Total number of } \\
\text { hours in cham- } \\
\text { ber }\end{array}$ & $\begin{array}{l}\text { Percentage of } \\
\text { germination }\end{array}$ & $\begin{array}{l}\text { Average final } \\
\text { length of roots } \\
\text { in } \mathrm{mm}\end{array}$ & $\begin{array}{l}\text { A verage final } \\
\text { length of shoots } \\
\text { in } \mathrm{mm}\end{array}$ \\
\hline 0 & 48 & I68 & 90 & 35 & I4 \\
\hline I & 36 & I68 & 85 & 20 & IO \\
\hline 2.5 & 48 & I 44 & 75 & 12 & 8 \\
\hline 5 & 96 & 138 & 60 & 8 & 5 \\
\hline 10 & no germinat'n & 336 & 0 & 0 & 0 \\
\hline
\end{tabular}

II. Avena sativa.

\begin{tabular}{l|l|l|l|l|l}
\hline 0 & 48 & I68 & 95 & 20 & 12 \\
I & 36 & I68 & 85 & I & 9 \\
2.5 & 96 & I44 & 80 & I I & 5 \\
5 & 96 & I44 & 80 & 8 & 3 \\
I0 & no germinat'n & 336 & 0 & 0 & 0 \\
\hline
\end{tabular}

III. Phaseolus vulgaris.

\begin{tabular}{l|c|c|c|c|}
\hline 0 & 40 & 168 & 100 & 18 \\
I & 24 & 168 & 100 & 15 \\
2.5 & 68 & 144 & 95 & 8 \\
5 & 96 & 144 & 85 & 6 \\
I0 & no germinat'n & 330 & 0 & 0 \\
\hline
\end{tabular}

IV. Cucurbita Pepo.

\begin{tabular}{l|c|c|c|c|}
\hline 0 & 36 & 168 & 95 & 18 \\
I & 24 & 168 & 95 & 17 \\
2.5 & 60 & 144 & 100 & 15 \\
5 & 84 & 144 & 50 & 10 \\
I0 & no germinat'n & 336 & 0 & 0 \\
\hline
\end{tabular}

When the seeds were placed in an atmosphere containing $5^{c 0}$ of ether, germination was still more strongly retarded; although, as in the preceding case, the effect was greater upon some seeds than upon others. Germination of corn was retarded 48 hours, while oats did not germinate until 144 hours after they were 
placed in the ether atmosphere, i. e., 48 hours after the corn had begun to germinate under the same conditions. Growth proceeded very slowly in the atmosphere of ether, so that at the end of seven days, while the roots of corn and oats under normal conditions were from 20 to $35^{\mathrm{mm}}$ in length, the roots of corn in the atmosphere of ether measured only from 6 to $10^{\mathrm{mm}}$ and the roots of oats from 4 to $\mathrm{I} 2^{\mathrm{mm}}$ (tables I and II).

In the series of experiments in which $10^{\text {ce }}$ of ether were used it seemed to be impossible for the seeds to germinate, regardless of the length of time they were left in the atmosphere of ether. Some seeds were left fourteen days, and even longer, without showing any signs of germination. Whether the life of the seeds in this strong atmosphere of ether was destroyed or whether vital action was simply suspended, was the point next considered. After the seeds had remained from seven to ten days in the atmosphere containing $10^{\mathrm{ce}}$ of ether, they were transferred to an ether-free atmosphere and placed under the same conditions as the control experiments. At the expiration of forty-eight hours a number of the seeds began to germinate. This was the same length of time required for germination by the seeds in the control experiment; hence it was concluded that the influence of ether for a period of seven days not only did not destroy the life of the seeds, but also did not injure them; $i$. e., the vital activity of the seeds seemed to be only suspended. When the seeds were left for twelve days in the atmosphere containing $10^{\mathrm{ec}}$ of ether, and were then transferred to an etherfree atmosphere, they seemed to have lost their vitality. It was noticed, however, that after the seeds had remained ten or twelve days in the ether atmosphere, they developed patches of mold (mostly Penicillium), and white and yellow spots, which proved upon examination to be patches of bacteria. However, those seeds which remained free, or comparatively free, from mold and bacteria, seemed to have lost their ability to germinate, showing that it was the influence of the ether, and not of the mold, that rendered the seeds unable to germinate. Similar results appeared both in regard to the inability of the seeds to 
germinate and in regard to the appearance of mold and bacteria when $15^{\text {cc }}$ of ether were used.

In order to free the seeds from germs and spores of fungi, they were soaked several hours in 0.5 per cent. solution of copper sulfate. A number of seeds were then placed in an etherfree atmosphere, and others in a damp chamber containing $1 \mathrm{O}^{\mathrm{cc}}$ of ether. More than 50 per cent. of the grains of corn that were placed in the ether-free atmosphere germinated in from three to five days, which was double the time required for the germination of similar seeds when soaked in pure water only, Contrary to the preceding experiments, the shoots or leaves appeared first, and attained, in most cases, a length of $5^{\mathrm{cm}}$ before the roots appeared, while in the few seedlings in which the latter did appear, they did not exceed $\mathrm{I}^{\mathrm{cm}}$ in length. The oat grains were still more strongly affected by the copper. sulfate, and did not begin to germinate until ten days after they were placed in the damp chamber. When the leaves had attained a length of from 2 to $3^{\mathrm{cm}}$ no roots whatever had appeared, while if copper sulfate was not used, the roots appeared first, as in the case of the corn, and attained the greater length. On comparing the behavior of these seeds with those that had been placed in an atmosphere of ether after soaking in copper sulfate, it was found that at the end of four days several grains of corn had begun to germinate, and that none of the seeds remained free from fungi. From the fact that none of the seeds soaked in pure water and transferred to an atmosphere containing $\mathrm{IO}^{\mathrm{cc}}$ of ether germinated, it would seem that the copper sulfate had a tendency to neutralize the influence of the ether. From lack of time, however, experiments were not carried further in this direction.

\section{EXPERIMENTS WITH SPORES.}

The peculiar behavior of the fungi, which often appeared on the seeds in spite of all precautions, called for systematic investigation of the action of ether upon these organisms. Accordingly, several series of experiments were carried through, in 
which spores of Mucor and Penicillium were used. For these experiments fresh spores were placed upon a mixture of 5 per cent. gelatin and Io per cent. sugar, and these preparations were then placed in damp chambers, containing respectively O.I, $\mathrm{I}, 2.5,5$, and $1 \mathrm{O}^{\mathrm{cc}}$ of ether, one chamber remaining free from ether for control.

TABLES V, VI. SPORES.

Spores placed on a medium of gelatin 5 per cent., sugar Io per cent. Temp. $18-20^{\circ} \mathrm{C}$.

\section{Mucor.}

\begin{tabular}{|c|c|c|c|c|}
\hline $\begin{array}{l}\text { Cc. of ether in } \\
\text { chamber }\end{array}$ & $\begin{array}{l}\text { No. hours re- } \\
\text { quired for ger- } \\
\text { mination }\end{array}$ & $\begin{array}{l}\text { No. hours from } \\
\text { germination to } \\
\text { formation of } \\
\text { new spores }\end{array}$ & $\begin{array}{l}\text { Total duration } \\
\text { of experiment } \\
\text { (hours) }\end{array}$ & Appearance of mycelia \\
\hline $\begin{array}{l}0 . \\
0 . \mathrm{I} \\
\text { I. } \\
2.5 \\
5 . \\
\text { I0. }\end{array}$ & $\begin{array}{r}14 \\
14 \\
14 \\
24 \\
36 \\
*_{2} 40\end{array}$ & $\begin{array}{c}24 \\
24 \\
24 \\
24 \\
\quad 24 \\
\text { No spores }\end{array}$ & $\begin{array}{r}38 \\
38 \\
38 \\
48 \\
60 \\
288\end{array}$ & $\begin{array}{c}\text { Branched } \\
\text { ". } \\
\text { Short and blunt } \\
\text { Blunt at first, then elong'd } \\
\text { Elongated } \\
\text { Long and branched }\end{array}$ \\
\hline
\end{tabular}

\section{Penicillium.}

\begin{tabular}{l|r|r|r|c}
\hline 0. & I2 & 28 & 40 & Branched \\
0.1 & 12 & 28 & 40 & " \\
I. & 12 & 28 & 40 & Short \\
2.5 & 24 & 24 & 48 & " \\
5. & 36 & 36 & 72 & Long and branched \\
I0. & +216 & $\mp 264$ & 1440 & White, long and branched \\
\hline
\end{tabular}

*If at end of 240 hours spores were placed on the nutritive medium in an etherfree atmosphere the spores germinated in 14 hours, and in 24 hours a few spore cases and spores had formed.

†Spores in this stage if removed and placed in an ether-free atmosphere grew rapidly and produced new spores in 40 hours.

\#If these new spores were placed on the nutritive medium they germinated in the usual time ( 12 hours) and produced fruit in 40 hours. The characteristic blue color was present.

The $0 . \mathrm{I}^{\mathrm{ec}}$ of ether seemed in some instances to accelerate germination slightly. This point was somewhat difficult to determine however, since the normal period of germination does not exceed fourteen hours under the conditions used.

In the damp chamber containing $I^{c c}$ of ether, many of the 
spores had germinated at the end of fourteen hours, but the appearance of the hyphæ under these conditions was in strong contrast to those under normal conditions. Instead of being long, slender, and tapering, like normal hyphæ, they were short and blunt, and often enlarged at the ends as if they were growing against some object which was offering resistance. It should be added that at the end of the next twenty-four hours the hyphæ had so overcome the influence of the ether that they had assumed the normal form, size, and stage of development, i.e., they had already produced spores. The fact that these plants had attained the same size as the plants in the control experiments, would indicate that growth must have been accelerated after the first fourteen hours, since at that time they were much dwarfed.

In the chamber that contained $5^{c c}$ of ether, the spores had simply become enlarged and granular at the end of fourteen hours, and it seemed as if they were unable to push out a tube at any point. At the end of the next twenty-four hours, many of these spores had germinated, and the hyphæ produced were similar in appearance to the hyphæ in the control experiments, except that there was no indication of spores or of spore cases.

When the spores were placed in an atmosphere containing $\mathrm{IO}^{\mathrm{cc}}$ of ether, germination was retarded for about ten days, at the end of which time many of the spores germinated without removal from the ether atmosphere. If the spores were removed at the end of five days and placed in an ether-free damp chamber, nearly all of them germinated within fourteen hours, but the subsequent growth was not so rapid as it was during the first twenty-four hours in the control experiments. At the end of the second twenty-four hours, the hyphæ showed rapid growth and a few spores were produced, but they were far less numerous than in the control experiments. At the end of ten days when the spores had begun to germinate, some of them were removed and placed in an ether-free atmosphere, and these spores grew more rapidly than those which remained in the ether atmosphere. 
The spores of Penicillium grew more rapidly than the spores of Mucor, whether they remained in the ether atmosphere or were removed to an ether-free atmosphere, and in both cases the Penicillium had formed an abundance of spores at the end of thirty-six hours after germination. The Penicillium that had begun to germinate at the end of ten days in the ether atmosphere was left undisturbed during the next twenty days, remaining throughout this time perfectly white, instead of assuming its characteristic bluish-green color, although it was full grown; and the spores had formed in abundance. It was also observed that the patches produced by the fungus did not seem to increase in size, as if the spores formed in the ether-atmosphere had lost power to germinate. When those spores were removed and placed in an atmosphere free from ether, they germinated in about twelve hours, produced fruit in forty hours, and assumed the characteristic bluish-green color. If a still stronger atmosphere of ether was used, e. $g ., 15^{c c}$, the results were practically the same as if only $10^{\text {ce }}$ of ether were used.

\section{CONCLUSIONS.}

Since it is evident that an atmosphere of ether of proper strength is capable of preventing the vital action of seeds and spores without necessarily destroying the life of those organisms, it is important to inquire into the cause of this inactivity. Is it due to the inability of the ferment to transform the food material into compounds that may be used by the plants; or is it due to some influence produced upon the protoplasm?

To investigate this first point, definite quantities of starch solution were placed in test tubes to which equal quantities of diastase were a jded, and also definite quantities of ether, varying from $0 . I^{\text {ce }}$ to $\mathrm{IO}^{\mathrm{ce}}$. Several test tubes containing no ether were provided for comparison. It was observed that the starch in the tube containing $\mathrm{O} . \mathrm{I}^{\mathrm{ce}}$ of ether was transformed under the influence of the ether even more readily than in the control experiment, a circumstance that agrees with the observations of Puriewitsch in his interesting work, "Physiologische Untersuch- 
ungen über die Entleerung der Reservestoffbehälter." ${ }_{4}$ In the other test tubes where larger quantities of ether were used, there seemed to be no appreciable difference in the time required for the transformation of the starch when compared with the control tubes. This also agrees with the observations of Puriewitsch ${ }^{5}$ and others; hence it would seem that the inactivity caused by the ether atmosphere is due to the influence produced upon the living protoplasm.

\section{SUMMARY.}

I. A weak atmosphere of ether tends to hasten the time of germination of both seeds and spores.

2. A strong atmosphere of ether retards or prevents the germination of seeds and spores.

3. The extent of retardation depends upon the strength of the ether atmosphere up to a given point.

4. The time of retardation for the same strength of ether atmosphere is different for different seeds and spores.

5. Spores produced in a strong atmosphere of ether are able to germinate and to produce new spores as readily as when grown in an ether-free atmosphere.

6. Seeds and spores which are kept from germinating by the influence of ether for several days, will germinate as readily as if they had not been subjected to an atmosphere of ether, if they are removed to an ether-free atmosphere.

7. Ether does not render the ferment inactive.

Maryland Agric. College,

College Park, Md.

${ }^{4}$ Jahrb. für wiss. Botanik 31: 1-76. 1898.

5 Loc. cit. 


\section{$2 \mathrm{BHL}$ Biodiversity Heritage Library}

Townsend, Charles Orvin. 1899. "The Effect of Ether Upon the Germination of Seeds and Spores." Botanical gazette 27(6), 458-466.

https://doi.org/10.1086/327856.

View This Item Online: https://www.biodiversitylibrary.org/item/94861

DOI: https://doi.org/10.1086/327856

Permalink: https://www.biodiversitylibrary.org/partpdf/222976

\section{Holding Institution}

Missouri Botanical Garden, Peter H. Raven Library

\section{Sponsored by}

Missouri Botanical Garden

\section{Copyright \& Reuse}

Copyright Status: Public domain. The BHL considers that this work is no longer under copyright protection.

This document was created from content at the Biodiversity Heritage Library, the world's largest open access digital library for biodiversity literature and archives. Visit BHL at https://www.biodiversitylibrary.org. 